\title{
the congestion mitigation and air quality improvement program
}

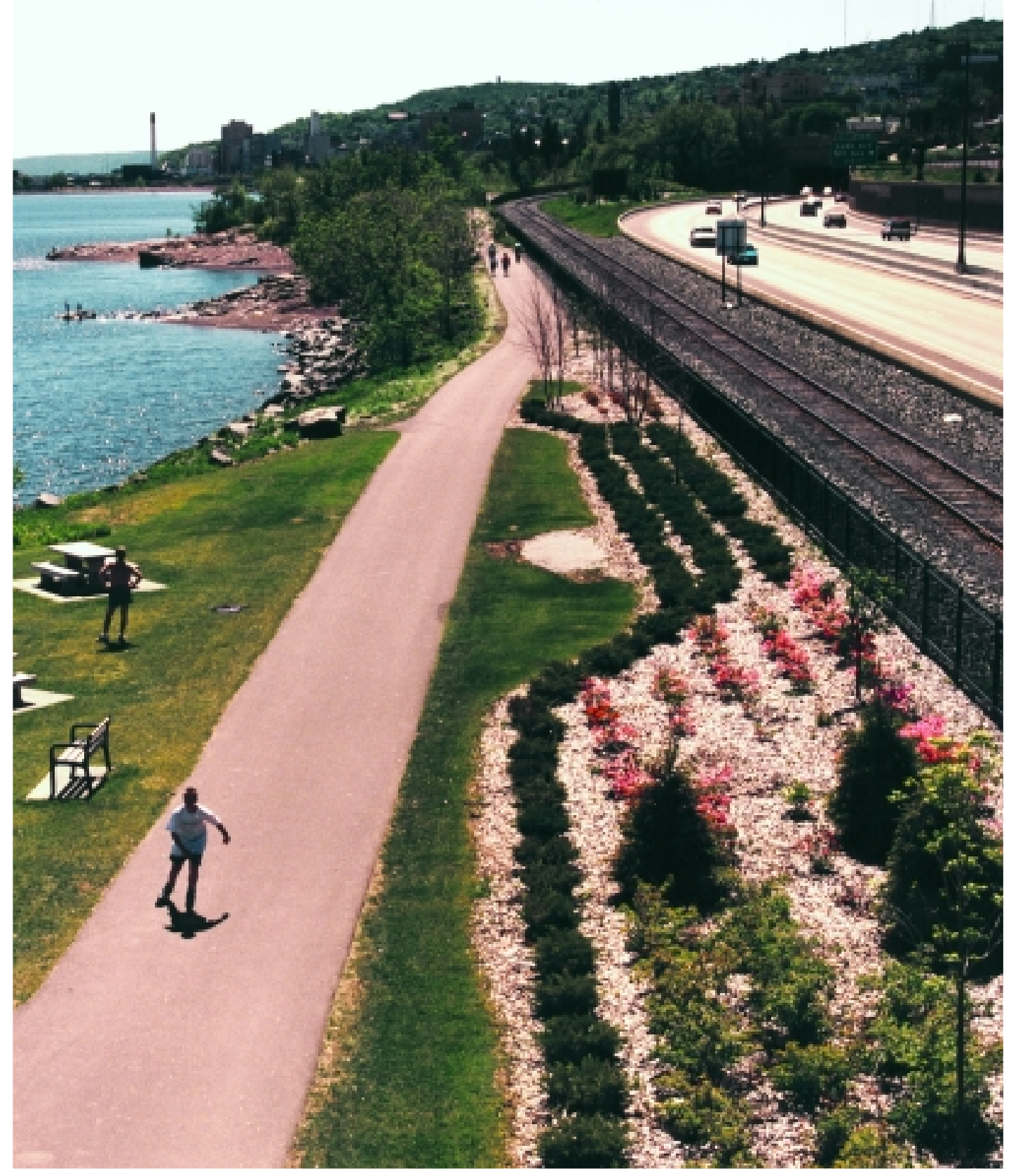




\section{Our vision is to create the world's Safest, most efficient and effective intermodal transportation system with the active participation and support of our partners throughout \\ government and in the private sector.}

\section{Notice}

This document is disseminated under the sponsorship of the Department of Transportation in the interest of information exchange. The United States Government assumes no liability for its contents or use thereof. 


\section{Contents}

Introduction

The Problem

Air Pollution and Traffic Congestion

The Response

The Congestion Mitigation and Air Quality Improvement Program

CMAQ and Air Quality

CMAQ and Congestion Relief

CMAQ and Livability

The Scale of CMAQ Projects

What's New

TEA 21 CMAQ Highlights at a Glance

CMAQ Funding

Maximizing the Benefits of CMAQ funding

Eligibility

Transit and Public Transportation Programs

Traffic Flow Improvements

Travel Demand Management Strategies

Ride Sharing Programs

Pedestrian and Bicycle Programs

Education and Outreach

Inspection and Maintenance Programs

Extreme Cold Start Programs

Alternative "Clean" Fuels

Public/Private Partnerships

Experimental Pilot Projects

Recipient Responsibilities

Reporting Requirements

CMAQ and Transportation Conformity

CMAQ Program Assistance, Project Proposals and the Federal Aid Process

Looking to the Future

Appendixes

Air Emissions Glossary

State Transportation Contacts

Metropolitan Planning Organization

Other Air Quality Resources 



\section{Introduction}

Clean air is an important part of a healthy environment. Unfortunately, many industrial and transportation activities that sustain our economy can also produce air pollutant emissions as byproducts, degrading our air quality. Safeguarding our air from such contamination is an important priority of the U.S. Department of Transportation (U.S. DOT), the Federal Highway Administration (FHWA) and the Federal Transit Administration (FTA).

The FHWA and FTA, in partnership with the States, Metropolitan Planning Organizations (MPOs), and local and private transportation entities, are preparing for the future. Our overall vision is to create the world's safest, most efficient and effective intermodal transportation system for the American people--a transportation system that provides access to everyone within and beyond their community; where crashes, delays, and congestion are significantly reduced; where freight moves easily and at the lowest costs; where roads protect ecosystems and travel on our roadways does not degrade the quality of the air; where pedestrians and bicyclists are accommodated; and

\section{Clean air is an important part of}

a healthy environment.

where essential transportation services are restored immediately after natural disasters and emergencies.

The FHWA and FTA goal to reduce delays on the transportation system and to protect and enhance the natural environment and communities affected by transportation is greatly advanced by the
Congestion Mitigation and Air Quality Improvement Program (CMAQ). The FHWA and FTA recognize that we cannot achieve our goals and objectives without the active participation and support of our partners throughout government and in the private sector. That is why we are bringing this information on the CMAQ Program to our stakeholders.

This brochure describes the CMAQ Program, a transporation air quality improvement program. It contains background and resource material for transportation planners, project applicants, environmental stewards and the general public. It includes information about application procedures, eligible projects and contacts for more information.

The FHWA and FTA goal to reduce delays on the transportation system and to protect and enhance the natural environment and communities affected by transportation is greatly advanced by the Congestion Mitigation and Air Quality Improvement Program (CMAQ). 


\section{The Problem}

\section{Air Pollution and Traffic Congestion}

Since the 1950s, we have known that vehicle exhaust fumes play a major role in the deterioration of air quality in urban areas. This knowledge led to widespread State and Federal regulatory activity, which eventually resulted in the passage of the modern Clean Air Act (CAA) in 1970.

The CAA gives the U.S. Environmental Protection Agency (EPA) the responsibility and legal authority to control air pollution by setting limits on pollution from stationary, area, and mobile sources of emissions. Federal standards, known as National Ambient Air Quality Standards (NAAQS), are required to be set at levels that protect human health. There are currently NAAQS for six pollutants. Those for which transportation sources are significant include carbon monoxide, particulate matter, and ozone. The most persistent pollution problem is ground level ozone, which is not emitted directly but is produced in the air during a complex photochemical reaction involving volatile organic compounds (VOCs) and oxides of nitrogen (NOx) contained in automobile exhaust emissions and other similar gasses.

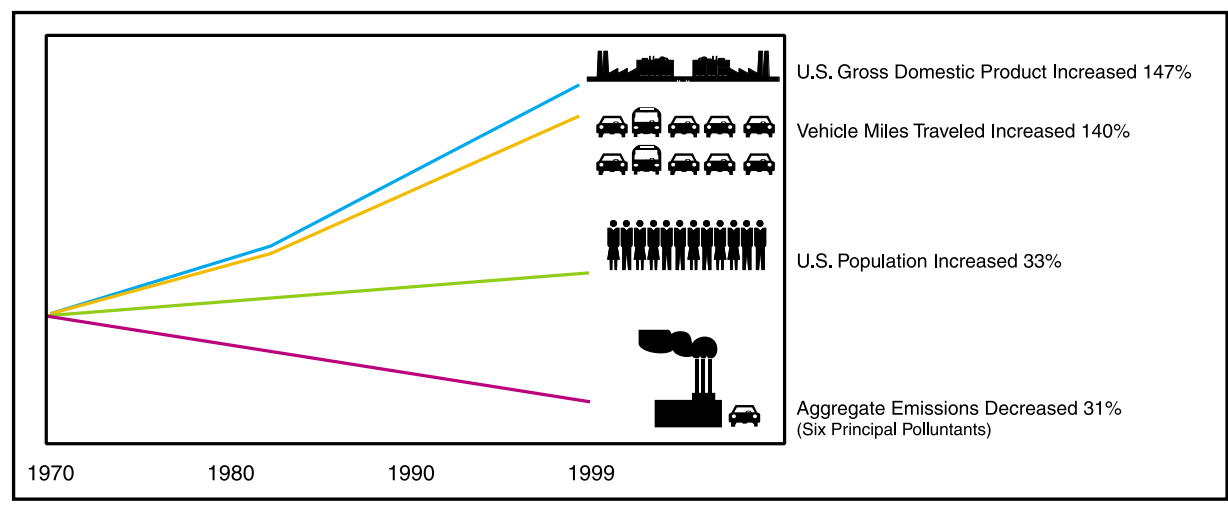

Figure 1. Comparison of Growth Areas and Emission Trends

\begin{tabular}{|ccc|}
\hline $\begin{array}{c}\text { Percent Decrease } \\
\text { in Concentrations } \\
(1989-1998)\end{array}$ & $\begin{array}{c}\text { Percent Decrease } \\
\text { in Emissions } \\
(1989-1998)\end{array}$ \\
\hline $\mathrm{CO}$ & -39 & -24 \\
\hline $\mathrm{O}_{3}$ & -4 (1 hour) & $\begin{array}{c}-26(\mathrm{VOC}) \\
+1(\mathrm{NO})\end{array}$ \\
\hline $\mathrm{PM}_{10}$ & -25 & -30 \\
\hline
\end{tabular}

The air is much cleaner than it was in 1970 even though further progress is necessary. For example, the EPA estimates that from 1989-1998 national emissions from mobile sources for carbon monoxide (CO) decreased 24 percent, 26 percent for VOCs and 30 percent for particulate matter (PM) less than 10 microns in size. These dramatic emission reductions occurred simultaneously with significant increases in economic growth and

Figure 2. Decrease in National Concentrations and National On-Road Mobile Source Emissions

Sources: Figures 1 - 3 - U.S. EPA. Latest Findings on National Air Quality: 1999 Status and Trends, August 2000. EPA-454/F-00-002 and U.S. EPA. National Air Quality and Emissions Trends Report, 1998, March 2000, EPA 454/R-00-003. 
population. Despite substantial progress in reducing emissions, the impact of mobile source air pollution continues to be large. EPA estimates that over 5,000 tons of VOCs from transportation sources were emitted in 1999 and that approximately 62 million people were living in areas that do not meet the health-based standards.

Fine particulate matter, or $\mathrm{PM}_{2.5}$, is defined as particles less than 2.5 microns in size. This pollutant causes adverse health effects by depositing in the lungs where it interferes with the respiratory process. The health risk from an inhaled dose of PM may depend on the size, composition, and concentration of the particulate. Combustion sources, including on-road vehicles, are thought to be significant to overall pollution levels of PM 2.5.

Large and densely populated metropolitan areas experience increased traffic congestion problems. The cost of traffic congestion to travelers is measured in hours of delay and wasted fuel. Travelers in the nation's 68 largest metropolitan areas spent over $\$ 72$ billion in hours of lost time

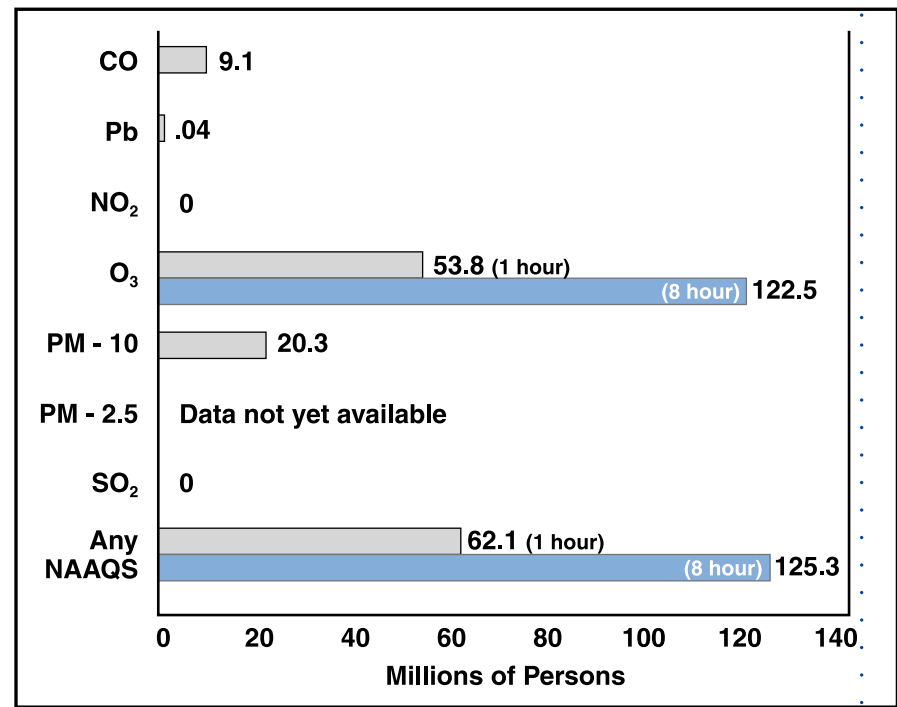

Figure 3. Number of People Living in Counties with Air Quality Concentrations Above the Level of the NAAQS in 1999

and wasted fuel in 1999. Between 1982 to 1997 the annual hours of delay per driver in the country's largest metropolitan areas increased by 125 percent, and in the small urban areas, the average increase was 400 percent. $^{1}$ Figure 4 displays the congestion increases experienced in many urban areas throughout the country. ${ }^{2}$

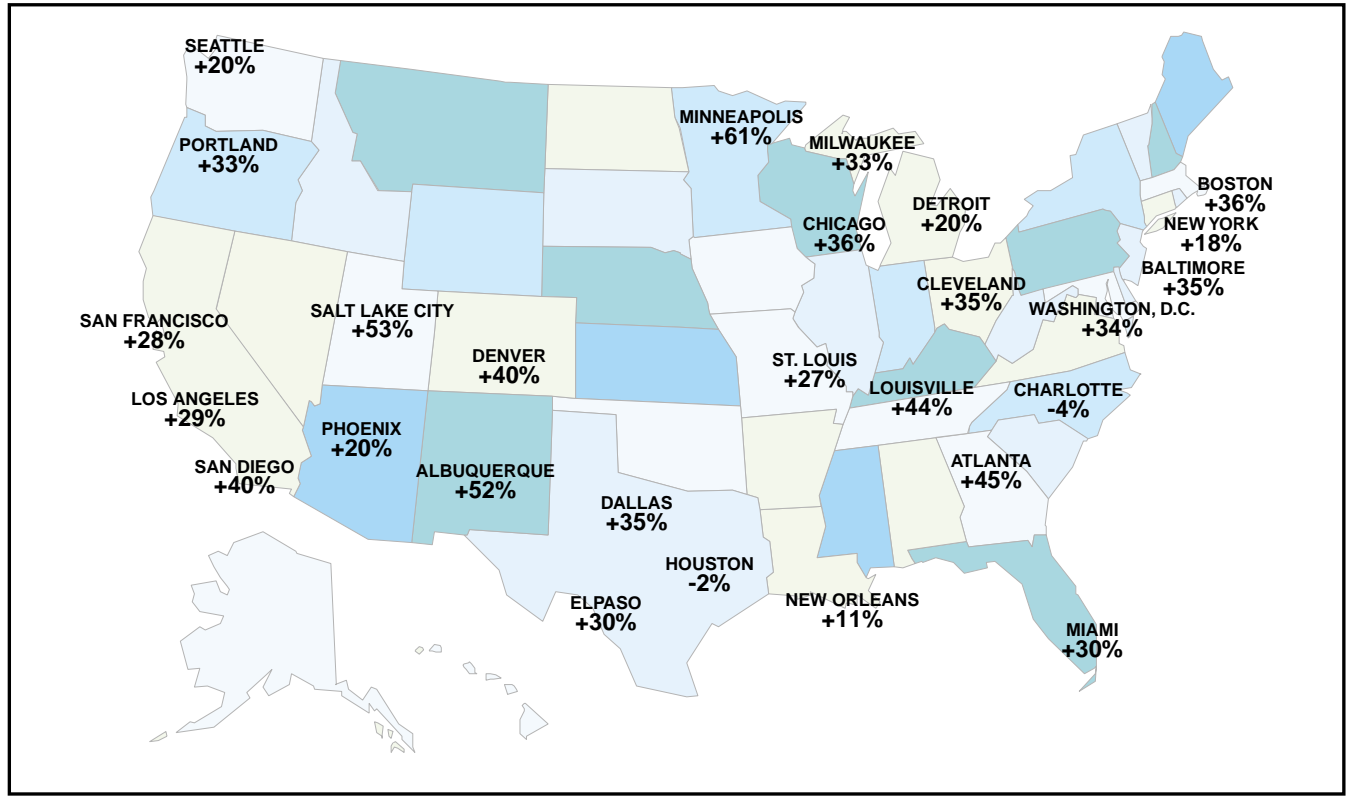

Figure 4. Percentage Change in Urban Congestion, 1982 to 1997

1 \& 2 Texas Transportation Institute. 1999 Annual Mobility Report, Appendix A-4 


\section{The Response}

\section{The Congestion Mitigation and Air Quality Improvement Program}

In 1990, Congress amended the Clean Air Act to accelerate America's efforts to attain the NAAQS. The amendments required further reductions in the amount of permissible tailpipe emissions, initiated more stringent control measures in areas that still failed to attain the NAAQS (nonattainment areas), and provided for a stronger, more rigorous linkage between transportation and air quality planning. The following year, Congress adopted the Intermodal Surface Transportation Efficiency Act (ISTEA) of 1991. This law authorized the Congestion Mitigation and Air Quality Improvement Program (CMAQ) to provide funding for surface transportation and other related projects that contribute to air quality improvements and congestion mitigation. The CAA amendments, ISTEA and the CMAQ program together were intended to realign the focus of transportation planning toward a more inclusive, environmentally-sensitive, and multimodal approach to addressing transportation problems.

\section{CMAO and Air Quality}

The main goal of the CMAQ Program is to fund transportation projects that reduce emissions in nonattainment and maintenance areas. Using State Departments of Transportation (State DOTs) estimates in 1997, total emissions reductions nationwide for CMAQ-funded projects were 170 tons per day for VOC and 430 tons per day for CO. While small in comparison to the reductions needed to attain the NAAQS, CMAQ funding has been proven to assist State DOTs and MPOs to meet their emission reduction requirements. Typically, under ISTEA, 89 percent of CMAQ-funded activities result in an estimated benefit of fewer than $100 \mathrm{~kg} /$ day or less while a much smaller percentage show significantly greater benefits. Figure 5 shows the distribution of expected VOC reductions for CMAQ-funded projects nationwide for FY 1997.

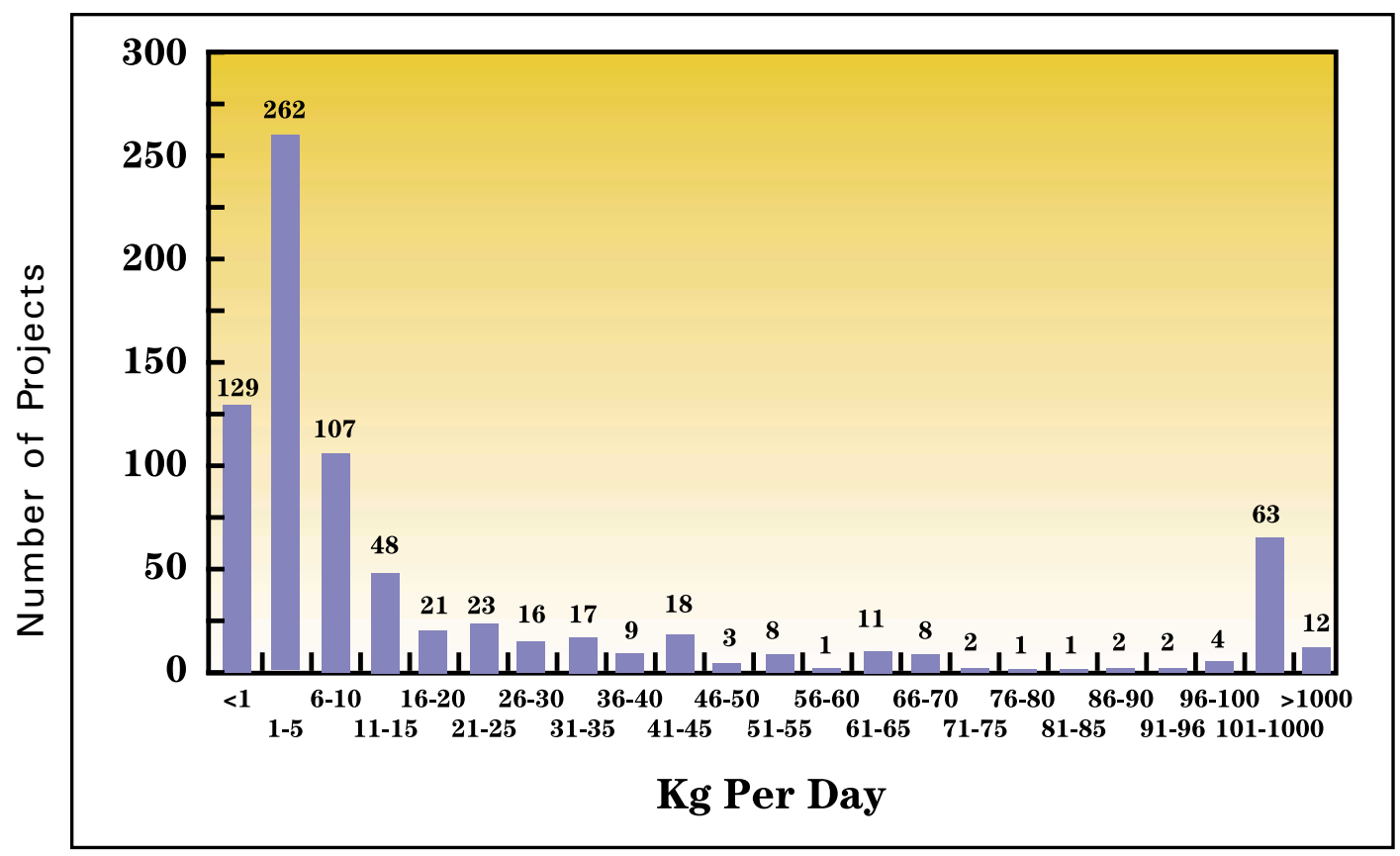

Figure 5. Expected Emission Reductions (VOC) 1997 


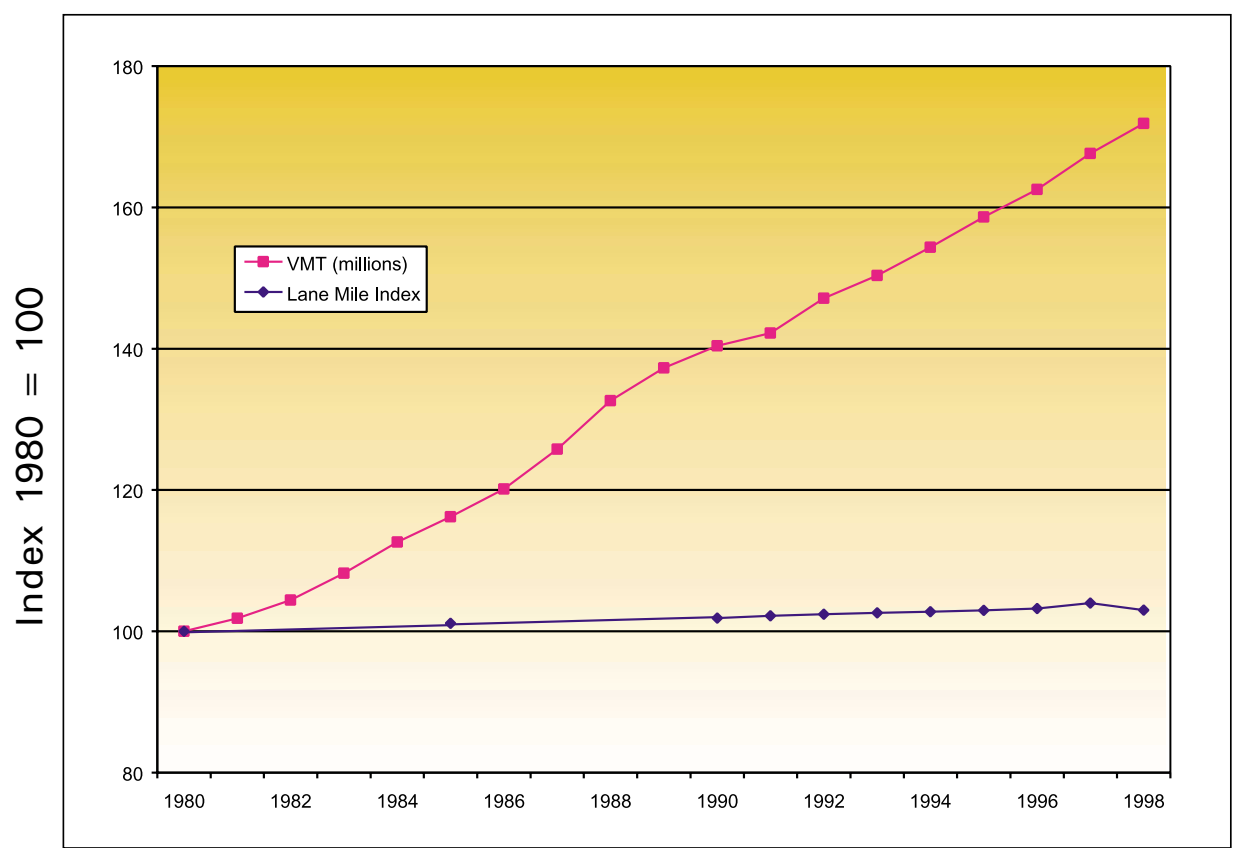

Figure $6^{4}$. VMT Versus Lane Mileage

Reductions in traffic congestion may decrease mobile source emissions as well as improve local economic competitiveness and productivity. However, given our current investment patterns, increasing levels of congestion are likely in the coming years. Our current course of runaway congestion is ---less and less--- a publicly acceptable option. In addition to the $\$ 72$ billion in lost time and wasted fuel, businesses located in areas with major travel delays face added costs associated with production delays, delivery difficulties, and diminished access to clients. While one alternative is to fund additional

The most effective CMAQ-funded projects tend to be large in scope and those that directly affect vehicle emissions, for example, Inspection and Maintenance VOC reductions range from 2 to 17 tons per day. ${ }^{3}$

\section{CMAO and Congestion Relief}

Congestion mitigation is also a goal of the CMAQ Program. Congestion relief can contribute to improvements in air quality by reducing travel delays, engine idle time and unproductive fuel consumption. And while emissions are generally being reduced nationally, most metropolitan areas are experiencing increases in congestion. Over the past twenty-five years, vehicle miles traveled (VMT) have more than doubled, while lane miles have increased slightly. (See Figure 6). This means that people are driving more and over a relatively static surface transportation system which is causing increased congestion. road construction to keep pace with traffic growth, this requires large capital expenditures, as well as other social and environmental costs that many communities are increasingly unwilling to accept.

Furthermore, there just may not be enough land where the need is greatest in dense urban cores. Part of the solution for these areas is to greatly improve the efficiency of the entire transportation network by increasing vehicle occupancy through better transit services, ridesharing and other demand management strategies; and managing our road systems better through Intelligent Transportation Systems and other traffic flow improvements. These improvements offer the mobility choices to reduce congestion and emissions, and CMAQ funding can help make these a reality. ${ }^{5}$

The CMAQ program is targeted at the areas of the country with the most severe air quality problems, which unsurprisingly represent the nation's largest

${ }^{3}$ Source: FHWA, 1997 CMAQ Annual Report.

${ }^{4}$ Sources: FHWA. Highway Statistics Summary to 1995, Highway Statistics Annual Reports 1996-1998; FHWA/FTA. 1997 Status of the Nation's Surface Transportation System; BTS. Transportation Statistics Annual Report 1998

${ }^{5}$ Source: Texas Transportation Institute. 1999 Annual Mobility Report. 
metropolitan areas. These areas are of tremendous importance. They account for 34 percent of the population, 45 percent of the national Gross Domestic Product, 34 percent of the employment, and comprise just 3 percent of the land area. If CMAQ funding were sub-allocated to these areas according to the federal apportionment formula applied to the States, they would receive more than 57 percent of all CMAQ funds nationally (see Table 1).

Table $1^{6}$

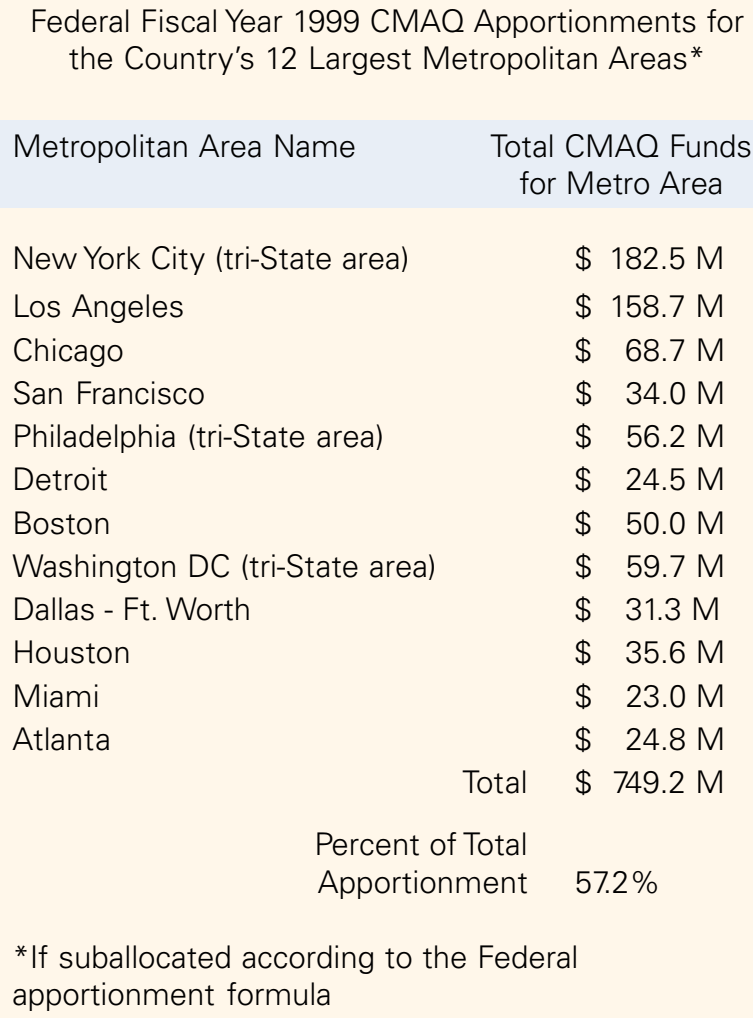

Percent of Total Apportionment

* If suballocated according to the Federal apportionment formula

Reducing congestion is an important goal for all metropolitan areas and CMAQ plays a role in both large and small metropolitan areas in slowing the growth of congestion, reducing emissions, and maintaining economically viable and mobile communities.

\section{CMAO and Livability}

Smog-free urban areas with good mobility underpin sustainable development goals, and a key benefit of CMAQ-funded projects is improved livability in an urban area. Areas with significant traffic congestion and bad air pollution are consistently rated poorly by the affected populations. Congestion is cited as the cause of "road rage" and other anti-social behavior. By addressing these key needs, CMAQ funding can help an area achieve a more livable environment for its inhabitants. Other quality of life benefits can also result from CMAQ funded projects. Bicycle and pedestrian improvements can make urban life much more enjoyable.

In addition to these benefits, the CMAQ Program has many indirect benefits such as including new stakeholders in transportation decisions, fostering project innovation, enhancing intermodal planning, and promoting savings in infrastructure investment. The future success of the CMAQ Program relies upon the continued participation of a diverse group of stakeholders. This diversity results in positive benefits for communities throughout the United States, because air quality decisions are subjected to a wider variety of input from representatives throughout communities and the public.

\section{The Scale of CMAO Projects}

CMAQ funding will not "solve" an area's air quality or congestion problems. Nor can it alleviate a great many urban problems, and dramatically improve an area's livability. It is one piece of a larger mosaic that can help in specific transportation corridors. For example, about $\$ 109$ billion was spent by all levels of government on highway and transit programs in 1995. CMAQ funding available to the States in that year was only about $\$ 1$ billion, or just 0.9 percent. Even single, albeit major, transportation infrastructure projects can cost in the billions of dollars, far exceeding total CMAQ funding.

As instructive as this comparison is to give a relative sense of scale, the proper comparison is not to the amount spent each year to maintain and improve the transportation network but to the total value of the network. While reliable estimates are not available, that figure is generally estimated to be in the trillions of dollars. When viewed in this context, CMAQ funding can only be viewed as providing incremental improvements to such a vast network. The appropriate way to view the potential of the CMAQ program is at the project or corridor level where the benefits of a single project can make a difference.

\footnotetext{
${ }^{6}$ Source: FHWA.
} 


\section{What's New}

\section{TEA-21 CMA0 Highlights at a Glance}

The 1998-2003 CMAQ program under the Transportation Equity Act for the 21st Century

(TEA-21) is a continuation of the innovative CMAQ program introduced under the ISTEA. The TEA-21 CMAQ program provides over $\$ 8.1$ billion dollars in funds to State DOTs, MPOs, and transit agencies to invest in projects that reduce emissions from transportation-related sources. In TEA-21, the CMAQ program received approximately a 35 percent funding increase in basic authorization levels. Additional activities were made eligible for funding and the statutory formula for apportioning funds was redesigned to provide a more equitable distribution of funds.

\section{CMAQ: The First Six Years}

The first six years of the CMAQ Program resulted in $\$ 4.6$ billion (of $\$ 5.5$ billion available after setasides) of funding for activities that assisted communities in reducing transportation related emissions, reducing congestion, and increasing public dialogue concerning pollution and transportation choices. The TEA-21 was designed to build and expand upon this success with the continued support of transportation partners and concerned citizens.

There are a variety of activities eligible for CMAQ funding (See FHWA Final Guidance for the CMAQ Improvement Program, published in the Federal Register, Volume 65, Number 36, Page 9040, February 23, 2000). According to the FHWA Annual Reports FY 1992-1997, during the first six years of the CMAQ Program, transit activities received the majority of the funding (43\%), followed by traffic flow improvements, such as Intelligent Transportation Systems (34\%), while the remaining activities such as pedestrian and bicycle, shared ride, and travel demand management, used the remaining funds.

CMAQ Funding By Project Type (FY 1992 - 1997.)

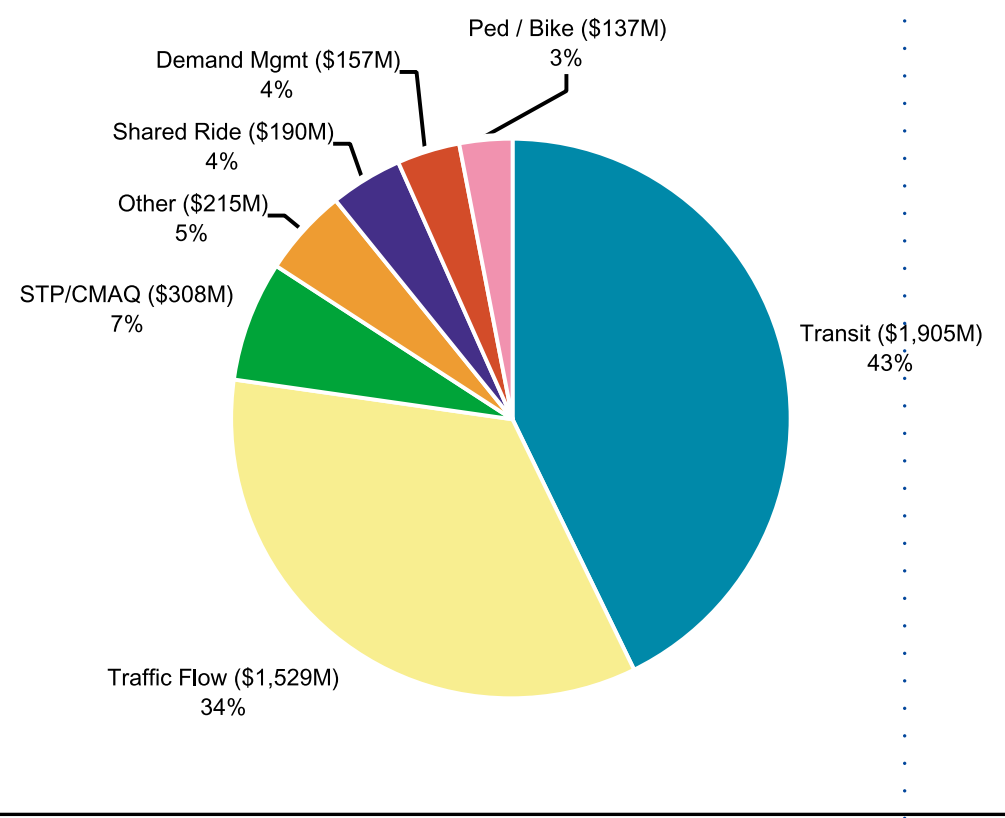


The TEA-21 CMAQ program is similar to its ISTEA

predecessor, but it features greater program

flexibility and several new program options (see

TEA-21 CMAQ Highlights).

\section{TEA-21 CMAO Highlights}

- Federal allocation formulas were adjusted so that areas designated as submarginal and maintenance for ozone are now in the CMAQ apportionment formula, and there are new weighting factors for $\mathrm{CO}$ nonattainment areas.

- CMAQ funding eligibility was expanded to include PM-10 nonattainment and maintenance areas.

- Extreme low temperature cold start emissions control programs and magnetic levitation transportation technology deployment projects were made eligible for funds.

- States were given more flexibility to develop CMAQ activities with non-governmental entities in order to attract private investment under public/private partnerships.

- A portion of CMAQ funds may now be transferred to other programs such as Bridge, Maintenance, Surface Transportation Programs or National Highway System projects if the annual CMAQ appropriation exceeds $\$ 1.35$ billion.

> States with minimum apportionment CMAQ funds have more flexibility regarding the use of their funds; they may use a portion of the funds for Surface Transportation Program purposes

> As with all Federal-aid programs, CMAQ authorized funds will be supplemented with "minimum guarantee" funds, assuring each State at least $90.5 \%$ of their trust fund revenues. 


\section{CMAQ Funding}

During the initial 1992-1997 CMAQ Program period, a total of $\$ 6$ billion was available for projects. Basic funding levels for the 1998-2003 TEA-21 program period were increased by 35 percent and are authorized at $\$ 8.1$ billion. The basic amount of available funding is determined by a formula calculation based on population and EPA's severity classification for ozone and carbon monoxide air pollution (See Figure 7).

These basic authorizations will be augmented, perhaps significantly, from two sources. The first is through the TEA-21 provision that guarantees each State a minimum of 90.5 percent of the funds that are paid into the Highway Trust Fund (HTF). Part of the funds needed to raise a State's total Federal-aid apportionment to this level are added to the CMAQ basic authorization. For example, in 1999 these minimum guarantee funds added $\$ 235$ million to the basic authorization. The second is through additions, part of which is added to the CMAQ program, which occur when the HTF revenues exceed projections. TEA-21 requires that authorization levels be realigned when this occurs. These funds under the Revenue Aligned Budget Authority are expected to increase CMAQ and other Federal-aid program funds substantially.

TEA-21 funds are apportioned to the State DOTs on an annual basis. Once the funds are apportioned to the State DOT, they are available for four years, and may be "obligated" or dedicated, to specific CMAQ projects.

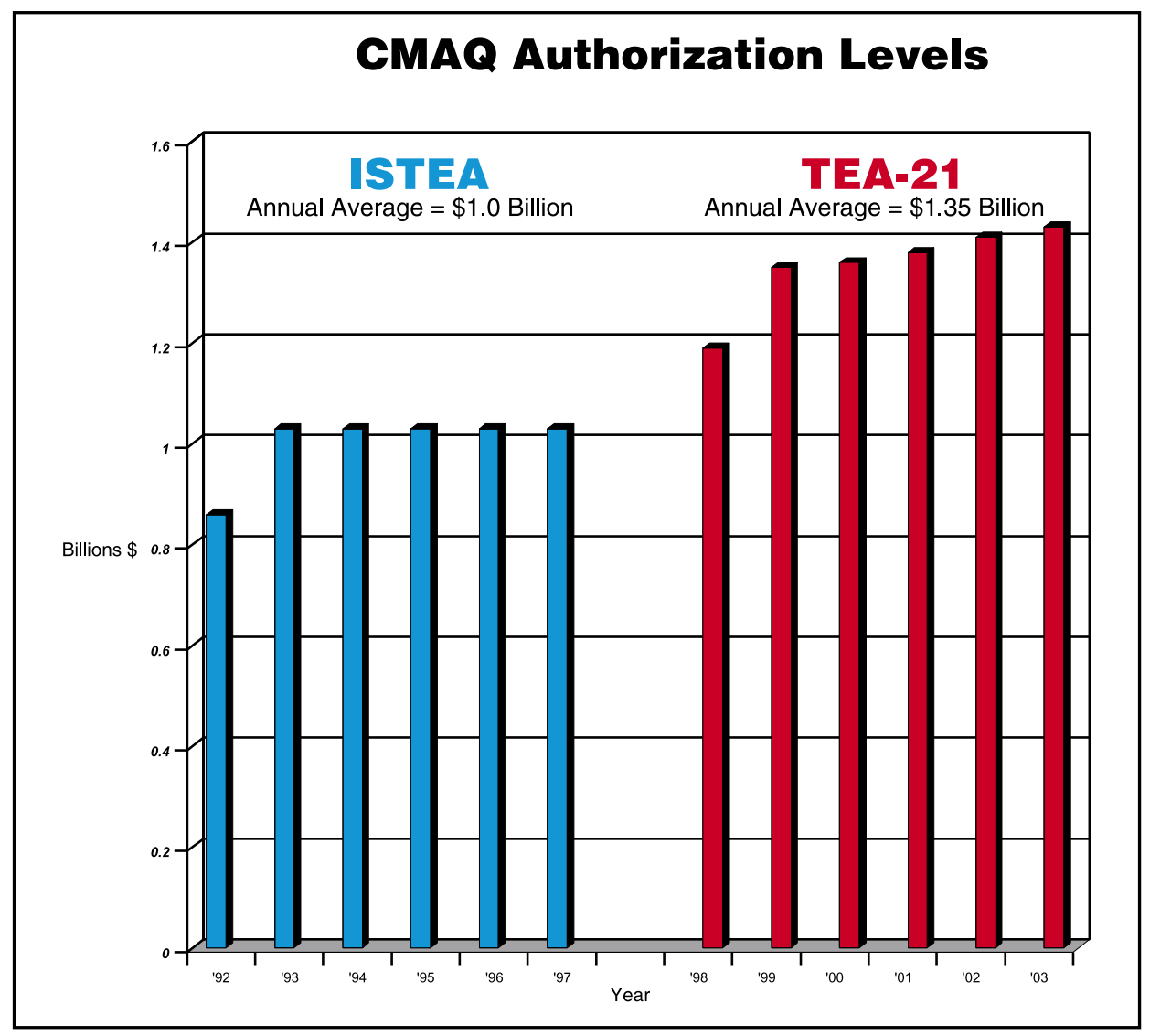

Figure $7^{7}$

\footnotetext{
${ }^{7}$ Sources: Intermodal Surface Transportation Efficiency Act (ISTEA) of 1991. Transportation Equity Act for the 21st Century (TEA-21) of 1998.
} 
The obligation of funds assures the project sponsor that federal monies are available and will be provided for authorized projects. However, CMAQ funds are only released as reimbursement payments for completed work. Unused funds lapse at the end of the four year availability period, and are no longer available for use by the State.

CMAQ funds require a state or local match. The typical split between federal and project sponsor is 80 percent Federal, 20 percent State and/or local match.

It is important to develop and fund CMAQ projects that will assist an area in reducing transportation-related emissions. Some projects may be more effective and cost-effective than other projects.

Under certain circumstances a portion of a State's CMAQ funds may be transferred to other Federalaid programs. This can only occur if the national CMAQ funding level for a given year is greater than $\$ 1.35$ billion dollars. If this occurs, a State may transfer up to fifty percent of the surplus actual CMAQ apportionment funds to other Federal-aid projects in the transportation improvement program. However, the transferred funds must still be obligated in nonattainment and maintenance areas. The amount of transferable funds will vary from year-to-year and from State-to-State depending on overall authorization levels. The FHWA is responsible for calculating the amount and tracking the transfer of the eligible CMAQ funds.

\section{Maximizing the Benefits of CMAO funding}

It is important to develop and fund CMAQ projects that will assist an area in reducing transportationrelated emissions. Some projects may be more effective and cost-effective than other projects. For some projects, project comparisons can be formulated by calculating an estimate for the amount of emission reductions per dollar spent. This cost-effectiveness analysis assists program managers with the evaluation of dissimilar CMAQ projects (for example, natural gas vehicles and refueling stations versus bike paths). Nevertheless, certain projects are more difficult to analyze. For example, in assessing the impacts of bicycle paths or a ride sharing program assumptions must be made about the number of automobile trips that will be reduced by people choosing these travel options.

Because CMAQ funds are limited compared to needs, planning officials should strive to maximize air quality benefits by allocating resources to the projects that are likely to achieve the greatest reduction in emissions. Consequently, projects that consistently reduce vehicle emissions for all trips may be more beneficial than projects which attempt to alter transportation demand for a particular trip, such as commuting which now constitutes only one-quarter of all trips. A thorough understanding of transportation demand, available resources and local traffic trends should indicate emission reduction strategies that are the most promising for a given geographical area.

The use of travel demand models may assist with the development of travel scenarios and model outputs can assist with estimating the corresponding emissions. Often, these models use many different inputs. FHWA can be contacted for a compilation of techniques that have been used to estimate emissions for a range of transportation projects. Research in this area continues to progress and tools to analyze the impacts of CMAQ funded projects are being continuously refined. While better modeling and improved analysis will almost certainly assist decisionmakers on which projects are estimated to yield better benefits, judgement and thoughtful consideration will also be necessary to select the best projects. 


\section{Eligibility}

Because CMAQ funds are intended to improve air quality, funds must be spent in nonattainment or maintenance areas. A nonattainment area is an area formally designated (in the Code of Federal Regulations) by EPA as not meeting the NAAQS. A maintenance area is an area that was nonattainment but has subsequently attained the NAAQS and was officially redesignated to attainment by EPA.

The CMAQ program strives to reduce transportation-related emissions by providing State DOTs and local governments options to fund different emission reduction strategies. For example, the CMAQ Program enables communities to increase public awareness concerning the links between transportation choices and air pollutions; provide technological applications to improve transportation system efficiency; increase transit services; or implement "Ozone Action" programs. Many of these activities could be Transportation Control Measures (TCMs). Most of the eligible categories of CMAQ projects are TCM-type activities and include a wide variety of measures to decrease vehicle emissions, primarily by reducing the total amount of vehicle miles traveled (VMT) in an area. Certain projects are ineligible for CMAQ funds. Legislative prohibitions exclude vehicle retirement programs and highway capacity expansion projects. Policy considerations exclude highway maintenance and reconstruction projects because these activities preserve existing levels of service and are unlikely to contribute to further improvements in air quality.

\section{Transit and Public Transportation Programs} CMAQ funds may be used to support the use of public transportation. There are three broad categories of transit projects or programs that are eligible for funding: service or system expansion; provision of new transit service; and financial incentives to use existing transit services. Service expansion strives to attract new users, typically by providing new transit facilities or additional transit vehicles. Improving intermodal connections in the major urban areas has been a focus since ISTEA and these projects are generally eligible for CMAQ funding.

The start-up of new transit service (e.g., new express bus routes or new shuttle service linking major activity centers) is supported under the CMAQ program in an effort to tap new markets for transit. While CMAQ cannot be a permanent source of funding for transit service, the goal is to encourage experimentation to determine whether new types of services are viable.

Financial incentive strategies attempt to encourage transit use, and include innovative fare policies as part of an overall effort to reduce exceedances of the air quality standards. Under specific conditions, CMAQ may be used to offset the cost of offering reduced or free transit fares. This can be done when the subsidized fare is an element of an overall, area wide strategy for reducing emissions during peak periods of ozone pollution.

Noteworthy transit success stories which were partially CMAQ-funded include the St. Louis Metrolink Program, an 18-mile light transit line that connects suburban communities with the city.

Another innovative project was the Boulder, Colorado Hop and Skip Community Transit System. The program received the 1999 FHWA Environmental Excellence Award. 

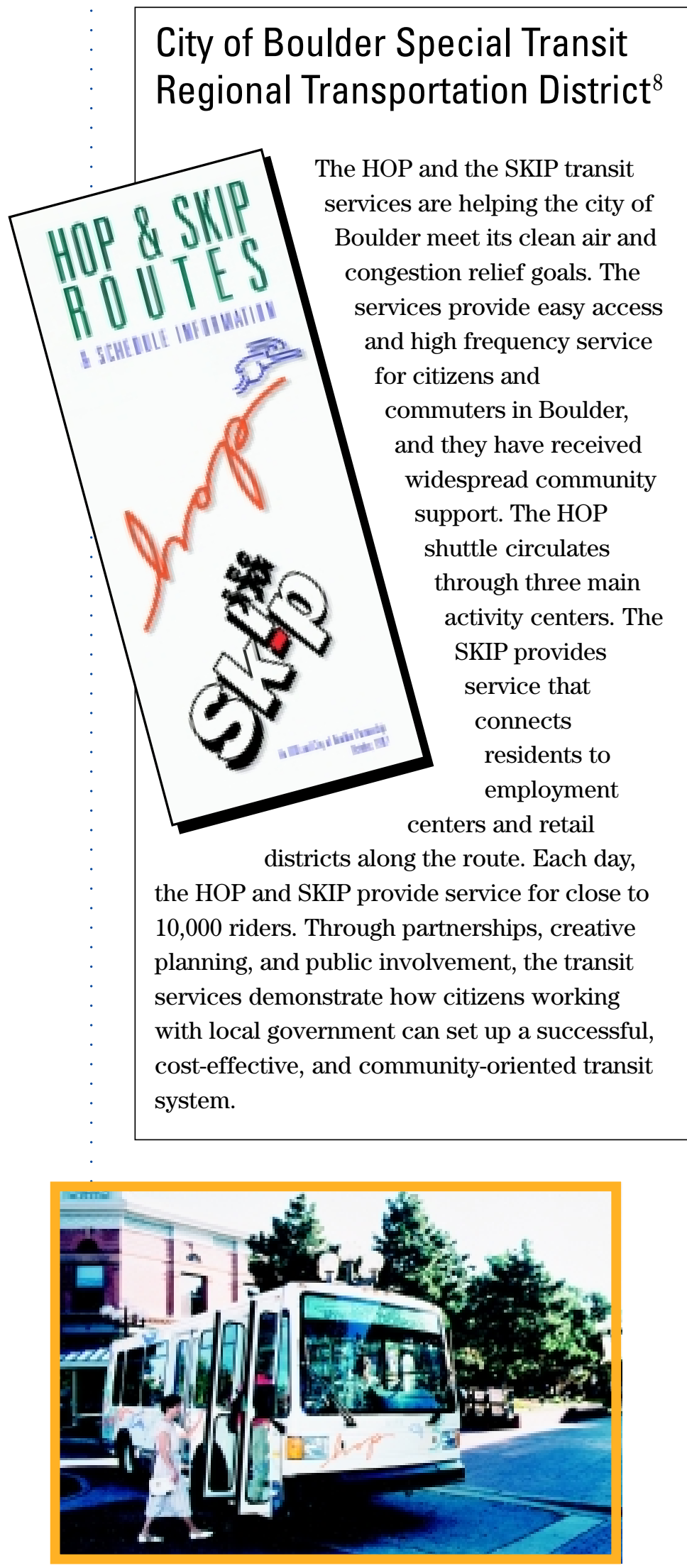

${ }^{8}$ Source: FHWA 1999 Environmental Excellence Awards

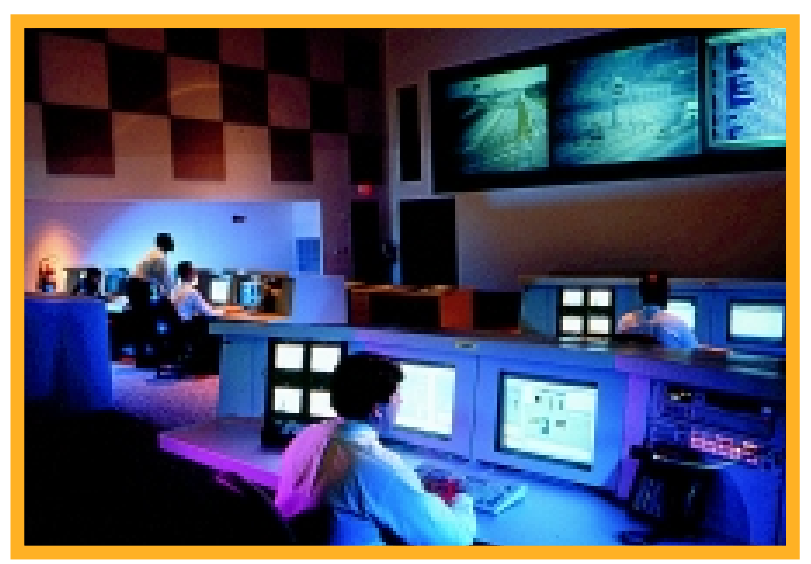

\section{Traffic Flow Improvements}

This strategy reduces emissions by promoting efficient traffic movement, thereby reducing unproductive travel delays and emissions resulting from engine idling. There are many ways to reduce and improve air quality by improving traffic flow. These include: traffic signal synchronization, channelization (to separate turning movements, for example), high occupancy vehicle lanes, and transportation management improvements. Of particular note are Intelligent Transportation Systems (ITS). The ITS efforts, using the very latest technologies, may be among the most innovative traffic flow improvement activities that are funded by CMAQ. In Fiscal Year (FY) 1997 the majority of CMAQ funds went to traffic flow improvements for the first time in program history, and much of this growth can be attributed to increased interest in ITS activities. FY 1996 and FY 1997 CMAQ funds were used for ITS projects that range from the ITS Early Deployment Plan in New York or the Traffic Operations Centers in New Jersey, Georgia and California to placing fiber optic cables in Texas and Kentucky's deployment of the Interstate Traffic Management Program.

\section{Travel Demand Management Strategies}

The demand for transportation can be moderated by adopting policy incentives that minimize the aggregate number of single occupancy vehicle trips and miles traveled. These strategies have grown substantially over the years and many metropolitan areas employ them to good advantage. Guaranteed Ride Home programs, employer outreach, public education, telecommuting, transportation management organizations, and other alternatives are also used to encourage trip reduction. 


\section{Ride Sharing Programs}

Ride sharing programs are designed to increase vehicle occupancy in an attempt to reduce emissions. This can be achieved by minimizing the total number of vehicles on the road and these programs are most effective for commuting purposes. Ride sharing programs tend to be most effective when participants save time or money by ridesharing, for example when high occupancy vehicle lanes are available that reward those traveling with 2 persons or more in a vehicle through reduced travel times.

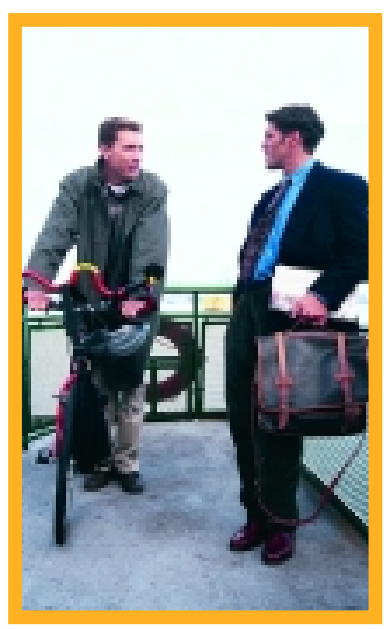

\section{Pedestrian and Bicycle Programs}

No mobile source emissions are produced by travelers using bicycles or walking, therefore, programs that promote these options are eligible for CMAQ funds. The substitution of bicycling and walking for relatively short trips is especially beneficial, because brief automobile trips result in

disproportionately large emissions caused by cold engine starts and fuel evaporation after the conclusion of the trip.

Bicycle programs may include the creation of trails, storage facilities, and marketing efforts designed to support bicycles as a form of transportation. The bicycle, as a viable transportation mode, has spurred many communities to incorporate bicycling facilities into urban plans, stimulating the reduction of motor vehicle emissions in some areas.

One such example is the Long Beach Bikestation in California which provides a convenient transfer point for riders on the adjacent light rail line. In addition, the Bikestation includes mechanics on site and provides secure bike lockers and rental bicycles. The Long Beach Bikestation has become a community hub for bicycle advocacy, transit information and community events.

\section{Education and Outreach}

CMAQ funding may be used to increase public knowledge of transportation-related emissions and opportunities to reduce them through mitigation strategies and improved transportation choices.

Successful education and outreach projects have included metropolitan public awareness campaigns, such as "Ozone Action" day programs that inform citizens about the causes of rising ozone levels during the day. Other activities have included public-private projects. One project in Houston-Galveston, Texas, assessed public resistance to transit and led to the development of compelling marketing materials, reduced fares and the targeted promotion of transit services and resulted in a significant increase in transit ridership.

\section{Inspection and Maintenance Programs}

Poor engine maintenance and malfunctioning of pollution control equipment can significantly increase the amount of emissions released per vehicle. According to EPA analysis, only 10 percent of the vehicles on the road produce 50 percent of the pollution. Consequently, CMAQ funds may be used to introduce, conduct and provide start-up costs for automobile inspection and maintenance programs.

\section{Extreme Cold Start Programs}

Several physical factors impact engine performance and increase emissions. Cold temperatures, and cold engine starts increase emissions because specialized exhaust equipment, such as catalytic converters, take time to warm up to the optimum operating temperature. While an important phenomenon everywhere, it is particularly crucial in cold-weather climates. CMAQ funds may be directed towards the development and implementation of programs that are designed to reduce or mitigate excessive cold start emissions. It is estimated that for a five mile trip, the cold car generates about 30 percent more NOx and 60 percent more carbon monoxide than starting the car when it is warm. 


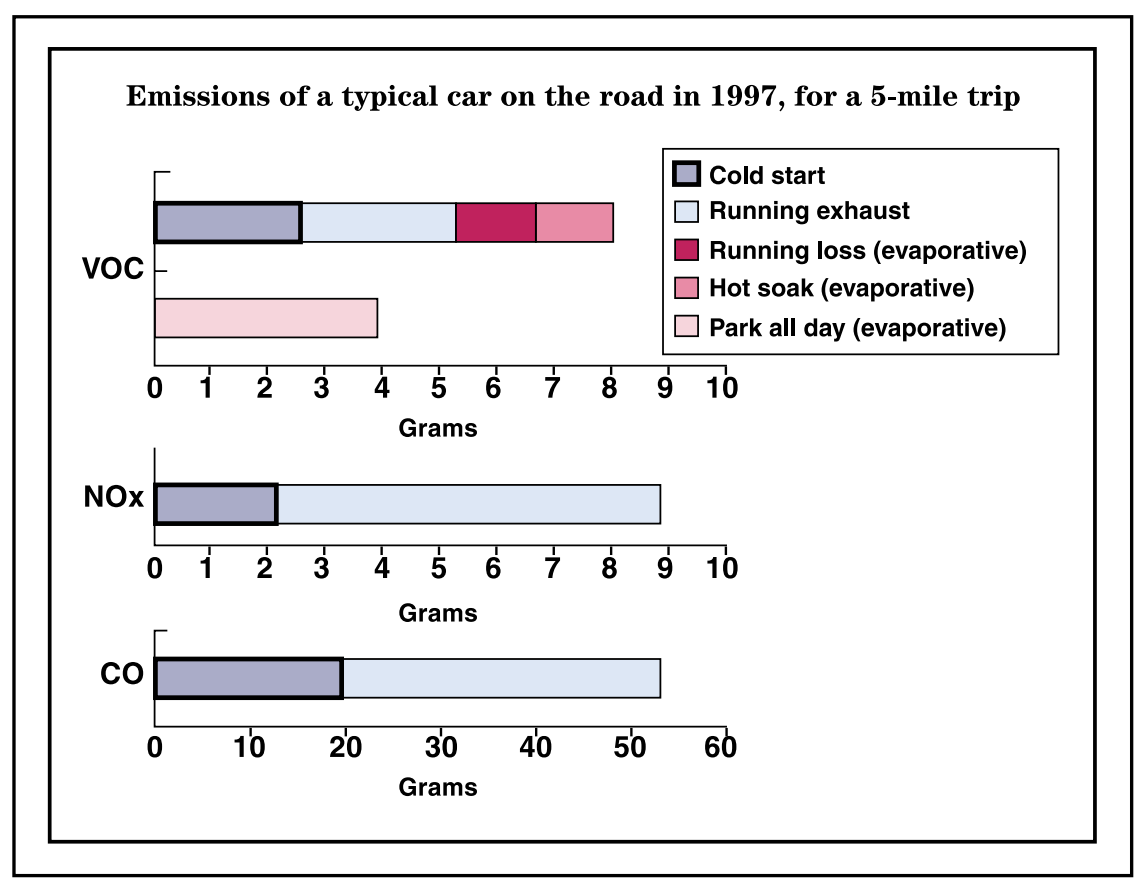

Figure $8^{9}$. Trip Emissions

\section{Alternative "Clean" Fuels}

Alternative or clean fuels are defined somewhat differently in the Clean Air Act and Energy Policy Act. But for CMAQ purposes an "alternative" fuel must reduce emissions to be eligible. These fuels can include natural gas, ethanol, methanol, electricity and liquefied propane gas. While a great many transit providers have used CMAQ funds for switching to alternative fuels, eligibility also extends to the purchase of vehicles and refueling equipment for other public agencies as well. And under TEA-21, eligibility can even extend to private companies (see Figure 8).

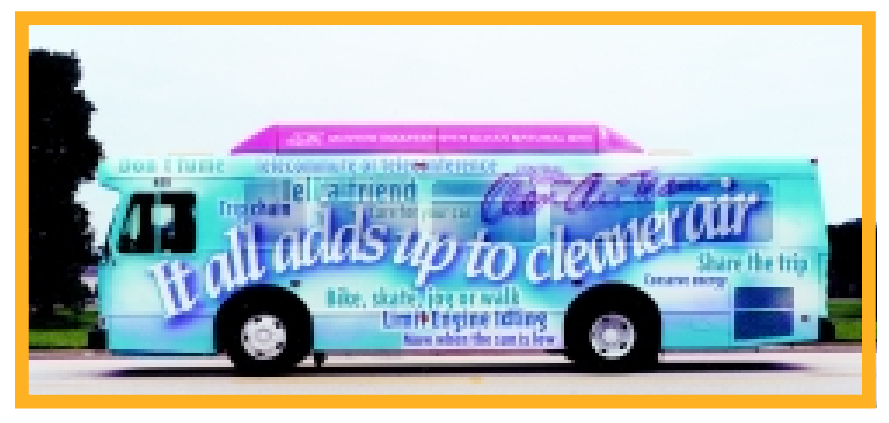

\section{Public/Private Partnerships}

Partnerships between public and private enterprises can leverage scarce funding resources by allowing private firms to own or operate a service developed with public funds. Often, public support is vital for projects that are not yet commercially viable because they lack markets sufficiently developed to stimulate private sector investment. TEA-21 eliminates some of the restrictions that previously limited private participation in emission reduction projects.

Some partnerships are ineligible for public funding because the private participation is mandated by law. CMAQ funds can not be used to help a private entity come into compliance with specific legal requirements, such as Clean Air Act or Energy Policy Act mandates. However, if the private entity clearly goes beyond the requirements, CMAQ funds may be used if the eligibility provisions are met. Furthermore, without public sponsorship or a contractual arrangement between a public agency and a private firm, CMAQ funds cannot be directed to the private sector.

\footnotetext{
${ }^{9}$ Source: FHWA, Transportation Air Quality Selected Facts and Figures, 1999, page 29
} 
Public agencies interested in a partnership project need to consider several institutional and administrative issues. Federal regulations are

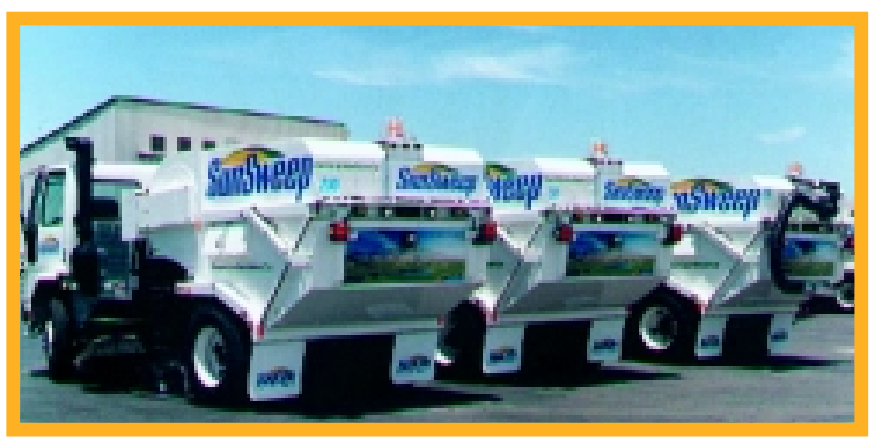

often a major challenge to people unfamiliar with the process. Local match provisions, reimbursement conditions, environmental clearances, and other requirements apply regardless of whether a project is implemented by a public or private entity. Public partners need to consider contract administration issues, including the length of a contract, and legal recourse in the event of contract performance deficiencies.

Private corporations interested in partnership arrangements need to be aware of program funding characteristics. Potential funding changes include annual appropriation levels or program cancellation. Private partnerships may need to produce satisfactory financial returns for shareholders, but these returns may be set by regulatory authorities in noncompetitive or monopoly market environments.

\section{Experimental Pilot Projects}

The CMAQ Program has proved overall to be a highly successful experiment in Federal transportation funding. However, there are many possible ways to use CMAQ funds in which Federal, State and local authorities may have little experience. Experimental pilot projects are innovative initiatives that are designed to provide a funding mechanism for well thought out strategies that extend beyond current experience and are not explicitly eligible under the law. Before and after evaluations are required to see if the experimental project has produced air quality benefits, and States may not use more than 25 percent of their annual CMAQ apportionment. Pilot projects are usually unique, with few precedents to guide the proposal and development process, but technical assistance is available from Federal agencies, including FHWA and FTA. Experimental pilots must meet all legal requirements - they must be reasonably classified as transportation projects; they must show potential to reduce emissions; and they cannot violate any legal restrictions.

\section{Recipient Responsibilities}

The project sponsor is usually responsible for assembling the proper documentation for CMAQ proposals. The requirements to apply for CMAQ funds vary by metropolitan area and State. Interested parties should contact their State DOT or MPO to find out the requirements for their nonattainment or maintenance area. Once the project is found eligible by FHWA or FTA, the recipient must follow through by supplying information necessary for the State DOT to adequately develop the required annual report. Every effort should be made by the project sponsors to quantify, or qualitatively assess, (if quantification is impossible), the proposal's benefits.

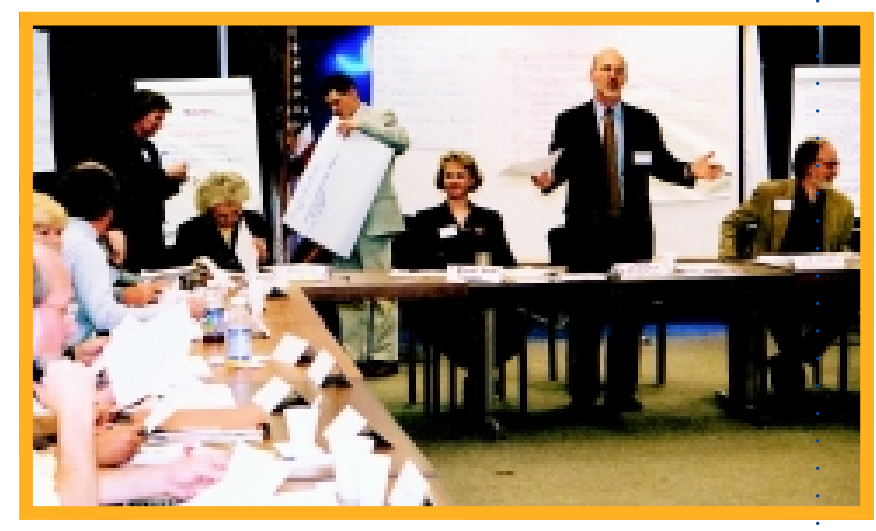

\section{Reporting Requirements}

The CMAQ Guidance requires State DOTs to provide FHWA with annual reports detailing their CMAQ projects. The report should list the CMAQ projects by category, and include information about emission reduction estimates and project costs. Generally, these reports are prepared on a Federal fiscal year basis. 


\section{CMAQ and Transportation Conformity}

In order to fund the best projects, transportation and air quality planning must be fully integrated. Without a comprehensive picture of an urban, nonattainment area's transportation and air quality needs, including detailed understanding of the interrelationship between congestion, travel growth, and transportation-related emissions, it will be extremely difficult to maximize the effectiveness of an area's CMAQ funding. At the nexus of transportation and air quality planning is transportation conformity. And CMAQ funding has, in many instances, been critical to making a conformity determination and maintaining the flow of Federal transportation funds without disruption.

\section{CMAQ funding has been crucial to}

avoiding costly disruptions in the

\section{Federal funding process.}

Transportation planning in metropolitan communities strives to maximize mobility and accessibility while simultaneously minimizing air pollution. The MPOs are composed of representatives from regional transportation organizations and local governments. Planning activities are initiated by MPOs and in order to achieve transportation goals, follow a formal "continuing, comprehensive and cooperative" planning process. The process begins with public participation and input that reflects the values and priorities of the community.

Conformity is a requirement of the CAA which states that transportation plans, programs and projects must "conform" to a state's plans to attain the air quality standards. A demonstration of conformity is required to receive federal funds and approvals before advancing projects. If the demonstration cannot be made, only certain projects may proceed until it can be.
Conformity brings together transportation and air quality planning. The MPO creates a 20 year transportation plan and the Transportation Improvement Program (TIP) which is a prioritized list of transportation activities in the MPO area. For an MPO in a nonattainment (or maintenance) area, the predicted air emissions from the plan and TIP must not exceed an emissions limit established by the State air quality agency. These documents embody the MPO's vision for addressing the area's transportation needs in consultation with the State DOT. By contrast, each State air quality agency is responsible for developing a plan to achieve the national air quality standards. The State Implementation Plan, referred to as the SIP, describes emission reduction efforts to attain the NAAQS and is subject to EPA approval. Without adequate planning to address both the transportation needs and for attainment of the standards, the conformity process can become unbalanced, making the demonstration of conformity problematic.

The CMAQ program, which has sometimes been referred to as the funding arm of the Clean Air Act, has a direct and important relationship with conformity and air quality compliance. It can be an important funding strategy for implementing such measures as CAA-required inspection and maintenance programs or conversions to alternative fuels. One of its greatest benefits has been toward assisting the demonstration of conformity.

When preliminary analysis indicates that conformity cannot be established, it may mean that the MPO and the State DOT must change the timing or mix of transportation projects in the Plan/ TIP, delaying or eliminating needed transportation improvements. An alternative to this is to identify emissions-reducing projects as offsets which may be funded under the CMAQ program. In this way, CMAQ funding has been crucial to avoiding costly disruptions in the Federal funding process. 


\section{CMAQ Program Assistance, Project Proposals and the Federal Aid Process}

CMAQ funds are available to a wide range of government and non-profit organizations, as well as private entities contributing to public/private partnerships, but are controlled by the MPO and the State DOT. Often, these organizations plan or implement air quality programs and projects as well as provide CMAQ funding to others to implement projects.

All phases of project development are eligible for CMAQ funds. However, to keep your project eligible for reimbursement, each phase must be approved prior to spending money ...

Organizations interested in obtaining CMAQ funding need to develop their ideas and prepare a project proposal using State DOT or MPO procedures. The project proposal must document how the project will provide emissions benefits before CMAQ eligibility is determined. Wherever possible, a quantitative emissions reduction estimate should be presented, although certain project categories, such as public education, marketing, or other outreach efforts are not easy to assess quantitatively. Instead, for these projects, a logical explanation of the emission reduction contribution and air quality benefit may be acceptable.
The process by which proposals for CMAQ funds are solicited is unique to each State and MPO. Therefore, project sponsors should pay careful attention to the submission guidelines and deadline schedules that are established in their State and/or MPO. The MPO is responsible for developing and prioritizing projects and works with the State DOT to set the CMAQ Program investment level. In some States, CMAQ funding is programmed and projects are selected every two years. Consequently, a missed deadline may create significant delays for a worthwhile CMAQ proposal.

As stated above, all projects which are to receive federal funding or approval must come from the latest conforming plan and TIP. All CMAQ projects must come from the fiscally constrained plan and TIP in order to be authorized. Authorization is the final approval that is given by FHWA or FTA. If you have a CMAQ project you would like to have funded, it must first be placed on the plan and TIP by the MPO. This process varies among MPOs and it is recommended you contact your MPO with your suggestions for CMAQ projects.

\section{Project Development and Environmental Clearance}

All federally funded projects have several stages, all of which require time, effort and coordination. The simplicity or difficulty of your project will dictate the amount of time and effort it requires. Projects funded with CMAQ must comply with laws created to protect the human and natural environment. 
There are a number of major milestones that are generally required for Federal-aid projects, including those under CMAQ. The agencies approving the project have certain responsibilities, as do the project sponsors. Once the project has received an eligibility determination from the FHWA or FTA, the project sponsor will be responsible for the planning, public involvement, environmental documentation, permits and approvals, design and development of plans, creation of right-of-way plans and acquisition of property, submission of procurement, bid and construction paperwork, selecting contractors and submission of materials for invoicing and annual reporting requirements. The Federal and State agencies provide environmental, right-of-way and utility clearances, and authorization (See Figure 9).

\section{Typical Project Development Process}

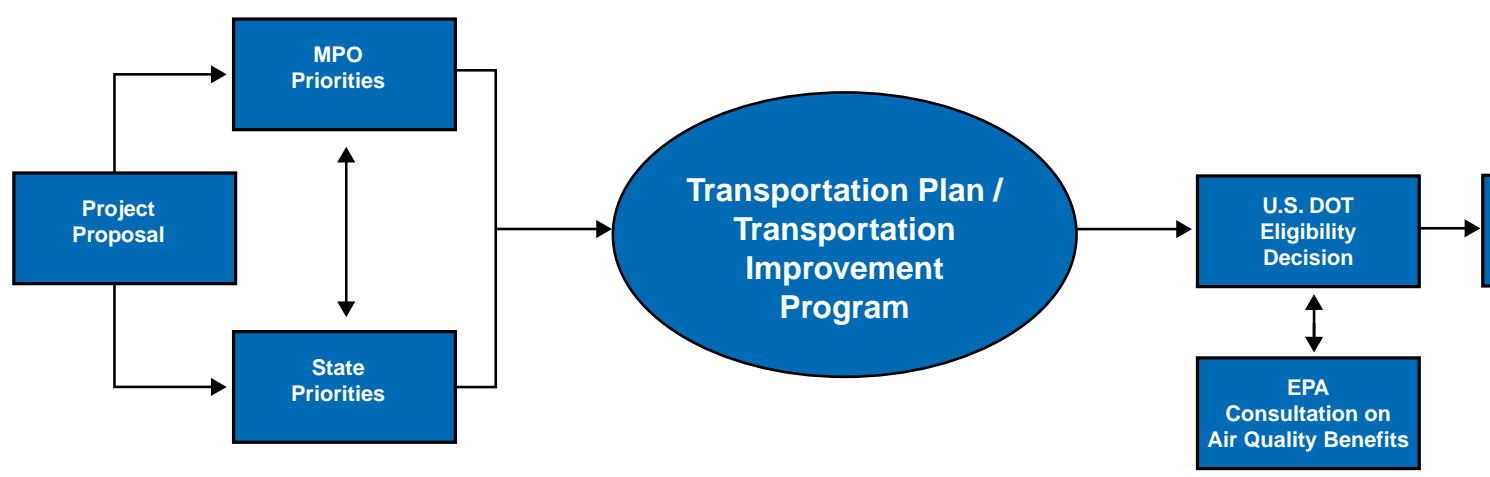

Environmental clearance

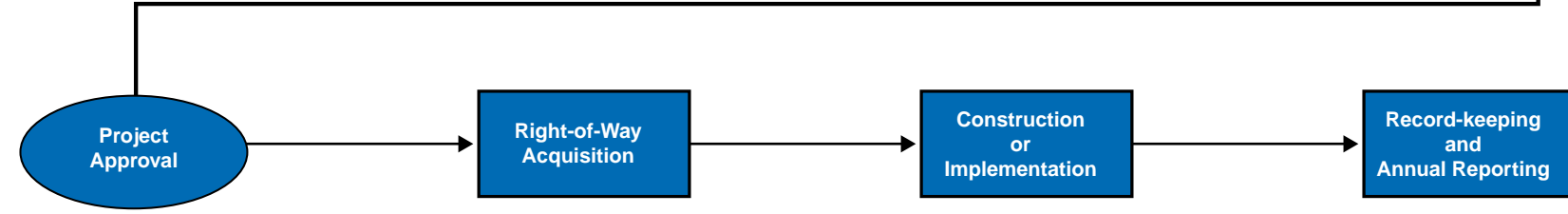

Figure $9^{10}$

${ }^{10}$ Source: FHWA 
Environmental clearance covers a range of activities that may be required to meet federal and state environmental laws. This includes the National Environmental Policy Act (NEPA), the National Historic Preservation Act (Section 106), the Uniform Relocation Act, and other relevant laws. The environmental documentation process is designed to help project sponsors and federal agencies make decisions. Compliance with NEPA is required for Federal-aid projects and can range from a simple determination of no significant impacts to a fully executed Environmental Impact Statement. Your CMAQ project will need final NEPA approval from FHWA or FTA prior to further funding. Some MPOs require NEPA to be complete prior to placing the construction phase of a project on the TIP. In order to complete the environmental clearance process you may be required to hold one or more public meetings.
If you have any right-of-way to purchase, there are established laws that must be followed prior to starting the transaction and must be completed to approve your document and fund your project.

All phases of project development are eligible for CMAQ funds. However, to keep your project eligible for reimbursement each phase must be approved prior to spending money, purchasing right-of-way or signing contracts.

Many CMAQ-eligible projects do not require all steps in the above process to be followed. In other words, certain projects can benefit from a greatly streamlined project development process (e.g., ride-sharing programs, vanpool programs, public education programs, etc.). The best course of action is to work closely with your MPO and/or State DOT to determine how best to ensure that all required legal and environmental requirements are addressed.

\section{The CMAQ program can aid communities in improving the quality of the natural environment by reducing highway- related pollution.}




\section{Looking to the Future}

Highways and transportation facilities have significant effects on the natural environment and on the quality of life in communities. Through Federal-aid programs such as CMAQ, we work with our partners to ensure that highway and transit facilities enhance the natural environment.

The CMAQ program can aid communities in improving the quality of the natural environment by reducing transportation-related pollution. The FHWA and FTA partner with States and MPOs to strengthen the links between transportation investments and communities by supporting and promoting increased transportation options and programs and projects to reduce environmental impacts.

The country's transportation system faces many special challenges. Lane mileage has increased slowly, while highway travel has increased rapidly. Increased congestion is a result of this disparity. The implementation of an integrated ITS infrastructure system with CMAQ funds is just one of the underlying strategies and initiatives associated with achieving the strategic objective of reduced congestion by improving the operations and efficiency of our surface transportation system.

Other challenges include the growth in the demand for travel, which serves to partially counteract the emissions benefits of cleaner cars and cleaner fuels. In addition, as the new NAAQS for ozone and fine particulate matter begin to phase in, States will face new challenges in meeting the air quality targets. In nonattainment and maintenance areas, the impending impacts of potentially stricter NAAQS are expected to increase the challenge of meeting the transportation conformity requirements. FHWA and FTA aim to reduce mobile source emissions by encouraging the use of less polluting transportation options and supporting the deployment of fuel- and emissionefficient vehicles. Many of these activities are eligible for CMAQ funds.

While the FHWA and FTA are proud of the contribution the CMAQ Program has made to reductions in mobile source emissions and congestion, the CMAQ Program's emissions impacts must be recognized as one relatively small part of the solution to a large and complex problem.

Over the first 9 years CMAQ has opened up the project selection process, helped reduce mobile source emissions and helped slow the rate of growth of congestion in some of the nation's largest cities. The goals of improved mobility and environmental protection are a delicate balancing act repeated throughout the country every day. Given the ever changing demands on the funding program, air quality standards and the transportation system, CMAQ will continue to provide improved funding opportunities to meet these challenges.

Given the ever changing demands on the funding program, air quality standards and the transportation system, CMAQ will continue to provide improved funding opportunities to meet these challenges. 


\section{Appendix I \\ Air Emissions Glossary}

\section{Carbon Monoxide (CO)}

Carbon monoxide is a colorless, odorless gas produced whenever incomplete fuel combustion occurs. In the United States, more than two-thirds of the carbon monoxide emissions come from transportation sources. In urban areas, motor vehicle contributions to carbon monoxide pollution can exceed ninety percent.

When inhaled, the gas forms carboxyhemoglobin, a compound that disrupts normal respiration by inhibiting the transfer of oxygen to specialized blood cells that transport the oxygen throughout the body. Symptoms from exposure include impairments in visual perception, manual dexterity, learning functions and the ability to perform complex tasks. Sensitive individuals, such as infants, the elderly or respiratory patients may be highly susceptible to acute symptoms of carbon monoxide poisoning.

\section{Particulate Matter $\left(\mathrm{PM}_{10}\right.$ and $\left.\mathrm{PM}_{2.5}\right)$}

Particulate matter consists of airborne solid particles and liquid droplets. These particles are classified as "coarse" if they are smaller than 10 microns, or "fine" if they are smaller than 2.5 microns. Coarse airborne particles are produced during grinding operations, or from the physical disturbance of dust by natural air turbulence processes, such as wind. Fine particles can be a by product of fossil fuel combustion, such as diesel and bus engines.

Fine particles can easily reach remote lung areas, and their presence in the lungs is linked to serious respiratory ailments such as asthma, chronic bronchitis and aggravated coughing. Exposure to these particles may aggravate other medical conditions such as heart disease and emphysema and may cause premature death. In the environment, particulate matter contributes to diminished visibility and particle deposition (soiling).

\section{Ozone $\left(\mathrm{O}_{3}\right)$}

Ozone is a chemically unstable molecule composed of three oxygen atoms. Ground level ozone is formed by sunlight and heat acting upon fuel combustion by products such as nitrogen oxides and hydrocarbons. Ozone occurs naturally in the upper atmosphere and shields the Earth from ultraviolet radiation. However, at ground level, ozone is a severe irritant and the primary component of "smog". In urban areas, at least half of the ozone producing components come from transportation sources such as automobiles. Because ozone formation is directly related to atmospheric temperatures, problematic ozone levels occur most frequently on hot summer afternoons.

Ozone exposure is linked to respiratory illnesses such as asthma and lung inflammation. Extended ozone exposure can exacerbate existing respiratory ailments such as chronic bronchitis and emphysema. Ozone pollution can severely damage vegetation including agricultural crops and forest habitats.

\section{Carbon Dioxide $\left(\mathrm{CO}_{2}\right)$}

Carbon dioxide is the by product of complete fuel combustion. Although it does not impair human health, the accumulation of carbon dioxide in the atmosphere is believed to contribute to global climate changes by trapping the earth's heat.

\section{Nitrogen Oxides $\left(\mathrm{NO}_{\mathrm{x}}\right)$}

Nitrogen oxides form when nitrogen and oxygen atoms chemically react inside the high pressure and temperature conditions in an engine. Nitrogen oxides are precursors for ozone, and in the environment, they contribute to the formation of acidic rain.

\section{Hydrocarbons (HC) or Volatile Organic Compounds (VOC)}

Hydrocarbon emissions are a product of partial fuel combustion, fuel evaporation and refueling losses caused by spillage and vapor leakage. Hydrocarbons react with nitrogen oxides and sunlight to form ozone. Some hydrocarbons are toxic and may be carcinogenic. 


\section{Appendix II \\ State Transportation Contacts}

STATES LISTED ALPHABETICALLY

Alabama Department of Transportation

1409 Coliseum Blvd.

Montgomery, AL 36130

(334) 242-6311

(334) 262-8041 Fax

web site: http://www.dot.state.al.us

Alaska Department of Transportation \& Public Facilities 3132 Channel Drive

Juneau, AK 99801-7898

(907) 465-3900

(907) 586-8365 Fax

web site: http://www.dot.state.ak.us

Arizona Department of Transportation

206 S. 17th Avenue

Phoenix, AZ 85007

(602) 255-7226

(602) 255-6941 Fax

web site: http://www.dot.state.az.us

Arkansas Department of Transportation

P.O. Box 2261, Little Rock, AR 72203

10324 Interstate 30, Little Rock, AR 72209

(501) 569-2211

(501) 569-2400 Fax

web site: http://www.ahtd.state.ar.us

California Department of Transportation

1120 N Street

P. O. Box 942673

Sacramento, CA 94273-0001

(916) 654-5267

(916) 654-6608 Fax

web site: http://www.dot.ca.gov

Colorado Department of Transportation

4201 E. Arkansas Ave.

Denver, CO 80222

(303) 757-9201

(303) 757-9656 Fax

web site: http://www.dot.state.co.us

Connecticut Department of Transportation

P. O. Box 317546 / 2800 Berlin Turnpike

Newington, CT 06131-7546

(217) 782-5597

(217) 782-6828 Fax

web site: http://dot.state.il.us

(860) 594-3000

(860) 594-3008 Fax

web site: http://www.state.ct.us/dot/
Delaware Department of Transportation

Highway Administration Center

P. O. Box 778 Bay Road, Route 113

Dover, DE 19903 Dover, DE 19903

(302) 760-2303

(302) 739-5736 Fax

web site: http://www.state.de.us/deldot/index.html

District of Columbia Department of Public Works

Reeves Center

2000 14th Street, N.W., 6th Floor

Washington, DC 20009

(202) 939-8000

(202) 939-8191 Fax

web site: http://www.publicworks.ci.washington.dc.us/ main.shtml

Florida Department of Transportation

605 Suwannee Street

Tallahassee, FL 32399-0450

(850) 414-5205

(850) 488-5526 Fax

web site: http://www.dot.state.fl.us

Georgia Department of Transportation

2 Capitol Square

Atlanta GA 30334

(404) 656-5206

(404) 656-3507 Fax

web site: http://www.dot.state.ga.us

Hawaii Department of Transportation

869 Punchbowl Street

Honolulu, HI 96813-5097

(808) $587-2150$

(808) 587-2167 Fax

web site: http://www.hawaii.gov/dot/

Idaho Transportation Department

3311 W. State Street

P. O. Box 7129

Boise, Id 83707

(208) 334-8807

(208) 334-3858 Fax

web site: http://www.state.id.us/itd

Illinois Department of Transportation

2300 S. Dirksen Parkway

Springfield IL 62764

web site: http://dot.state.il.us/ 
Indiana Department of Transportation Indiana Government Center North

100 N. Senate Avenue

Indianapolis IN 46204-2249

(317) 232-5526

(317) 232-0238 Fax

web site: http://www.ai.org/dot/

Iowa Department of Transportation

800 Lincoln Way

Ames, IA 50010

(515) 239-1111

(515) 239-1639 Fax

web site: www.state.ia.us/government/dot

Kansas Department of Transportation

Docking State Office

915 Harrison

Topeka KS 66612

(785) 296-3461

(785) 296-1095 Fax

web site: www.dot.state.ks.us

Kentucky Transportation Cabinet

State Office Building

High \& Clinton Streets

Frankfort KY 40622

(502) 564-4890

(502) 379-1851 Fax

web site: http://www.kytc.state.ky.us/

Louisiana Department of Transportation and Development

P. O. Box 942451201 Capitol Access Rd.

Baton Rouge, LA 70804-9245 / Baton Rouge, LA 70804

(504) 379-1200

(504) 379-1851 Fax

web site: http://www.dotd.state.la.us/

Maine Department of Transportation

State House Station 16

Augusta ME 04333-0016

(207) 287-2551

(207) 287-2896 Fax

web site: http://www.state.me.us/mdot

Maryland Department of Transportation

P. O. Box 8755

10 Elm Road

BWI Airport MD 21240-0755

(410) 865-1000

(410) 865-1334 Fax

web site: http://www.mdot.state.md.us/
Massachusetts Highway Department

10 Park Plaza

Boston MA 02116-3973

(617) 973-7868

(617) 973-8040 Fax

web site: http://www.magnet.state.ma.us/mhd/home.htm

Massachusetts Executive Office of

Transportation and Construction

10 Park Plaza, Suite 3510

Boston, MA 02116-3969

(617) 973-7000

(617) 523-6454 Fax

web site: http://www.state.ma.us/mhd/

Michigan Department of Transportation

State Transportation Building

425 West Ottawa

P. O. Box 30050

Lansing, MI 48913

(517) $373-2114$

(517) 373-0167 Fax

web site: http://www.mdot.state.mi.us

Minnesota Department of Transportation

395 John Ireland Boulevard

Room 411, Transportation Building

St. Paul MN 55155

(651) 297-2930

(651) 296-3587 Fax

web site: http://www.dot.state.mn.us/

Mississippi Department of Transportation

Woolfolk State Office Building 401 North West Street

P. O. Box 1850 10th Floor

Jackson MS 39215-1850 Jackson MS 39205

(601) 359-7001

(601) 359-7050 Fax

web site: http://www.mdot.state.ms.us/

Missouri Department of Transportation

Highway and Transportation Building

P. O. Box 270

Corner, Capitol \& Jefferson

Jefferson City MO 65102

(573) 751-4622

(573) 526-5419 Fax

web site: http://www.modot.state.mo.us

Montana Department of Transportation

2701 Prospect Avenue

Helena MT 59620

(406) 444-6201

(406) 444-7643 Fax

web site: http://www.mdt.state.mt.us/ 
Nebraska Department of Roads

1500 Nebraska Highway 2

P. O. Box 94759

Lincoln NE 65809-4759

(402) 479-4615

(402) 479-4325 Fax

web site: http://www.dor.state.ne.us

Nevada Department of Transportation

1263 S. Stewart Street

Carson City NV 89712

(702) 888-7440

(702) 888-7201 Fax

web site: http://www.nevadadot.com/

New Hampshire Department of Transportation John O. Morton Bldg.

Hazen Drive

P. O. Box 483

Concord NH 03301-0483

(603) 271-3734

(603) 271-3914 Fax

web site: http://www.state.nh.us/dot/

New Jersey Department of Transportation

1035 Parkway Avenue, CN-600

Trenton NJ 08625

(609) 530-3535

(609) 530-3894 Fax

web site: http://www.state.nj.us/transportation

New Mexico State Highway and

Transportation Department

State Highway Department Building

1120 Cerrilos Road, P.O. Box 1149

Santa Fe, NM 87504

(505) 827-5110

(505) 827-5469 Fax

web site: http://www.nmshtd.state.nm.us

New York Department of Transportation

Building 5, State Office Campus

Albany, NY 12232

(518) 457-4422

(518) 457-4190 Fax

web site: http://www.dot.state.ny.us

North Carolina Department of Transportation

P. O. Box 25201

1. S. Wilmington Street

Raleigh NC 27611

(919) 733-2520

(919) 733-9150 Fax

web site: http://www.dot.state.nc.us/DOT

North Dakota Department of Transportation

608 E. Boulevard Avenue

Bismarck ND 58505-0700

(701) 328-2581

(701) 328-1420 Fax

web site: http://www.state.nd.us/dot
Ohio Department of Transportation

1980 West Broad Street

Columbus, $\mathrm{OH} 43223$

(614) 4662335

(614) 466-0587 Fax

web site: www.dot.state.oh.us

Oklahoma Department of Transportation

200 N.E. 21st Street

Oklahoma City OK 73105

(405) 521-2631

(405) 521-2093 Fax

web site: http://www.okladot.state.ok.us/

Oregon Department of Transportation

355 Capitol Street, N.E.

Salem OR 97310

(503) 986-3200

(503) 986-3446 Fax

web site: http://www.odot.state.or.us/

Pennsylvania Department of Transportation

Forum Place

555 Walnut Street

Harrisburg, PA 17101-1900

(717) $787-5574$

(717) 787-5491 Fax

web site: http://www.dot.state.pa.us/

Puerto Rico Department of Transportation and Public Works

Office of the Secretary

P. O. Box 42007

San Juan PR 00940-2007

(787) 725-7112

(787) 728-8963 Fax

web site: http://www.dtop.gov.pr

Rhode Island Department of Transportation 2 Capitol Hill

State Office Building

Providence RI 02903

(401) 222-2481

(401) 222-6038 Fax

web site: http://www.state.ri.us

South Carolina Department of Transportation

Silas N. Pearman Building

955 Park Street

P. O. Box 191

Columbia SC 29202

(803) 737-1300

(803) 737-2038 Fax

web site: http://www.dot.state.sc.us 
South Dakota Department of Transportation 700 East Broadway Avenue

Pierre SD 57501-2586

(605) 773-3265

(605) 773-3921 Fax

web site: www.state.sd.us/state/executive/dot

Tennessee Department of Transportation 700 James K. Polk Building

Fifth and Deaderick

Nashville TN 37243-0349

(615) 741-2848

(615) 741-2508 Fax

web site:www.state.tn.us/transport

Texas Department of Transportation Dewitt C. Greer Highway Building

125 E. 11th Street

Austin TX 78701-2483

(512) 305-9501

(512) 463-0283 Fax

web site: www.dot.state.tx.us

Utah Department of Transportation UDOT/DPS Complex

4501 S. 2700 West

Salt Lake City UT 84119

(801) 965-4113

(801) 965-4338 Fax

web site: http://www.sr.ex.state.ut.us

Vermont Agency of Transportation

State Administration Building

133 State Street

Montpelier VT 05633

(802) 828-2657

(802) 828-3522

web site: http://www.aot.state.vt.us

Virginia Department of Transportation 1401 E. Broad Street, Room 414

Richmond VA 23219

(804) 786-6675

(804) 786-6683 Fax

web site: http://www.vdot.state.va.us/

Washington Department of Transportation Room 3D25 Transportation Building

Jefferson Street at Maple Park

Mail Stop: KF-01

Olympia WA 98504

(360) 705-7054

(360) 705-6800 Fax

web site: http://www.wsdot.wa.gov
West Virginia Department of Transportation 1900 Kanawha Boulevard, E.

Charleston, WV 25305-0440

(304) 558-0444

(304) 558-4076 Fax

web site: http://www.wvdot.com

Wisconsin Department of Transportation 4802 Sheboygan Avenue

P. O. Box 7910

Madison WI 53707-7910

(608) 266-1114

(608) 266-9912 Fax

web site: http://www.dot.state.wi.us

Wyoming Department of Transportation 5300 Bishop Boulevard

P. O. Box 1708

Cheyenne WY 82003-1708

(307) 777-4484

(307) 777-4163 Fax

web site: http://www.wydotweb.state.wy.us/ 


\section{Appendix III}

Metropolitan Planning

Organization

For the Metropolitan Planning Organization in your area, consult the National Association of Regional Council's website at

www.narc.org/ampo/mposnet.html

\section{Appendix IV \\ Other Air Quality Resources}

Other Air Quality Resources: United States

Department of Transportation Contacts

Federal Highway Administration (FHWA)

FHWA

Office of Natural Environment

400 7th Street, SW, Room 3240

Washington, D.C. 20590

(202) 366-6724

http://www.fhwa.dot.gov/environment/cmaq.htm

Federal Transit Administration (FTA)

Office of Planning

400 7th Street, SW, Room 9413

Washington, D.C. 20590

(202) 366-4033

http://www.fta.dot.gov

Environment Protection Agency (EPA)

USEPA

Office of Transportation and Air Quality

2000 Traverwood Drive

Ann Arbor, MI 48105

http://www.epa.gov/otaq/transp.htm 



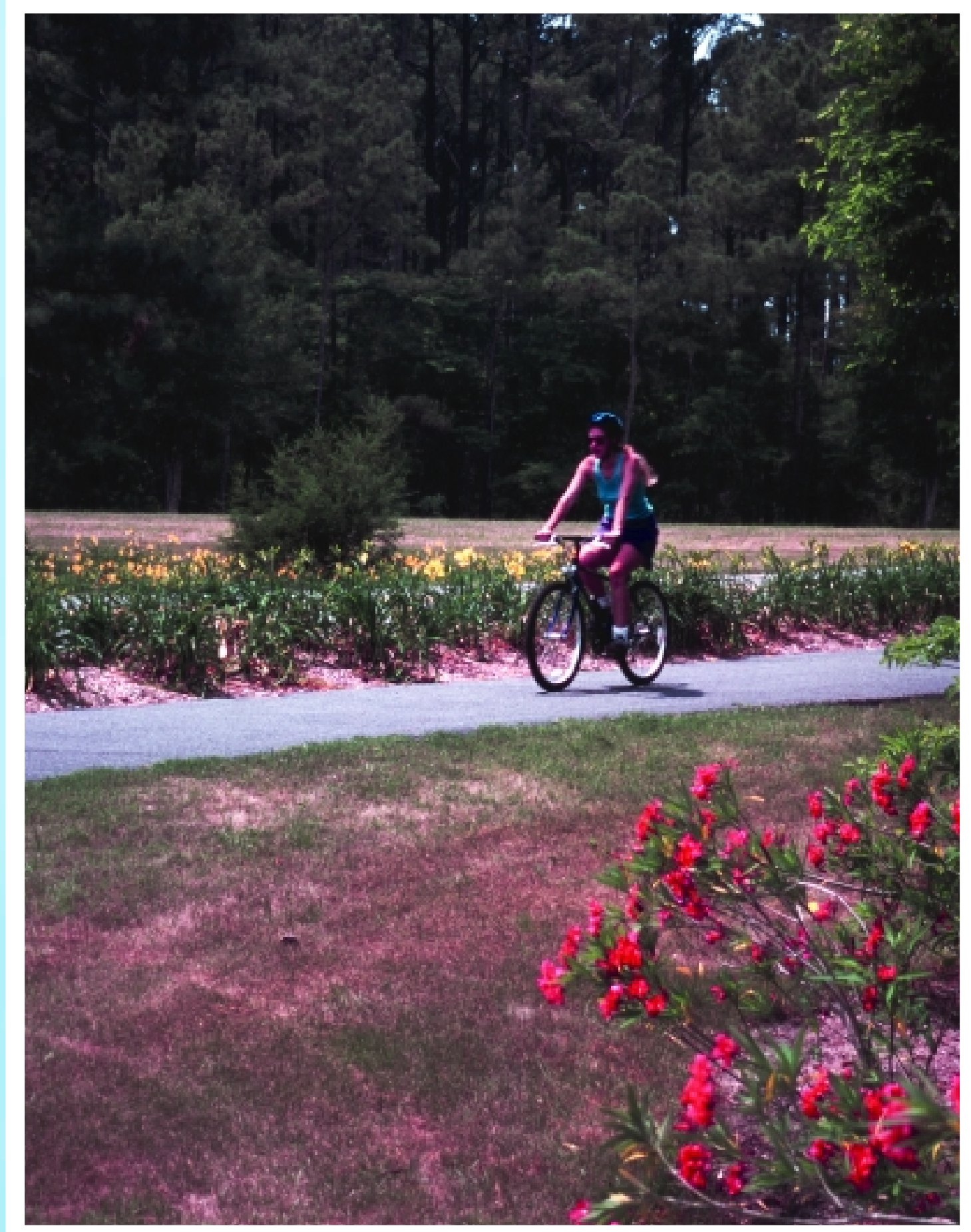

Publication No. FHWA-EP-00-020

HEPN-10/0-00(20M)E 